\title{
Gastrin-releasing peptide receptor-targeted gadolinium oxide-based multifunctional nanoparticles for dual magnetic resonance/ fluorescent molecular imaging of prostate cancer
}

\author{
This article was published in the following Dove Press journal: \\ International Journal of Nanomedicine \\ 12 September 2017 \\ Number of times this article has been viewed
}

\author{
Danting Cui' \\ Xiaodan Lu' \\ Chenggong Yan' \\ Xiang Liu' \\ Meirong Hou' \\ Qi $X_{i a}{ }^{2}$ \\ Yikai Xu' \\ Ruiyuan Liü,3 \\ 'Department of Medical Imaging \\ Center, Nanfang Hospital, Southern \\ Medical University, Guangzhou, \\ People's Republic of China; ${ }^{2}$ School \\ of Pharmaceutical Sciences, Southern \\ Medical University, Guangzhou, \\ People's Republic of China; ${ }^{3}$ School \\ of Biomedical Engineering, Southern \\ Medical University, Guangzhou, \\ People's Republic of China
}

Correspondence: Yikai Xu

Department of Medical Imaging Center, Nanfang Hospital, Southern Medical University, Guangzhou 5105I5, Guangdong, People's Republic of China Tel/fax +86206278 7333

Email yikaixu917@gmail.com

Ruiyuan Liu

School of Biomedical Engineering,

Southern Medical University,

Guangzhou 510515, Guangdong,

People's Republic of China

Tel/fax +86 2061648196

Email ruiyliu@smu.edu.cn

\begin{abstract}
Bombesin (BBN), an analog of gastrin-releasing peptide (GRP), specifically binds to GRP receptors, which are overexpressed in human prostate cancer (PC). Here, we synthesized a BBN-modified gadolinium oxide $\left(\mathrm{Gd}_{2} \mathrm{O}_{3}\right)$ nanoprobe containing fluorescein $\left(\mathrm{Gd}_{2} \mathrm{O}_{3}-5(6)\right.$ carboxyfluorescein [FI]-polyethylene glycol [PEG]-BBN) for targeted magnetic resonance (MR)/optical dual-modality imaging of PC. The $\mathrm{Gd}_{2} \mathrm{O}_{3}$-FI-PEG-BBN nanoparticles exhibited a relatively uniform particle size with an average diameter of $52.3 \mathrm{~nm}$ and spherical morphology as depicted by transmission electron microscopy. The longitudinal relaxivity $\left(\mathrm{r}_{1}\right)$ of $\mathrm{Gd}_{2} \mathrm{O}_{3}$-FIPEG-BBN $\left(r_{1}=4.23 \mathrm{mM}^{-1} \mathrm{~s}^{-1}\right)$ is comparable to that of clinically used Magnevist (Gd-DTPA). Fluorescence microscopy and in vitro cellular MRI demonstrated GRP receptor-specific and enhanced cellular uptake of the $\mathrm{Gd}_{2} \mathrm{O}_{3}$-FI-PEG-BBN in PC-3 tumor cells. Moreover, $\mathrm{Gd}_{2} \mathrm{O}_{3}$-FI-PEG-BBN showed more remarkable contrast enhancement than the corresponding nontargeted $\mathrm{Gd}_{2} \mathrm{O}_{3}$-FI-PEG according to in vivo MRI and fluorescent imaging. Tumor immunohistochemical analysis further demonstrated improved accumulation of the targeted nanoprobe in tumors. BBN-conjugated $\mathrm{Gd}_{2} \mathrm{O}_{3}$ may be a promising nanoplatform for simultaneous GRP receptor-targeted molecular cancer diagnosis and antitumor drug delivery in future clinical applications.
\end{abstract}

Keywords: magnetic resonance imaging, gadolinium oxide, bombesin, gastrin-releasing peptide receptor, molecular imaging

\section{Introduction}

Prostate cancer (PC) is one of the leading causes of cancer-related deaths worldwide. ${ }^{1}$ Because of its asymptomatic and multifocal nature, it has been challenging to accurately detect cancer lesions in early stages. ${ }^{2}$ Conventional imaging, which includes magnetic resonance imaging (MRI), computed tomography, and transrectal ultrasound, is routinely used for PC staging and prognostic determination. ${ }^{3}$ However, there is substantial room for improvement in the specificity and sensitivity of imaging for early staged PC.

Gastrin-releasing peptide receptors (GRPRs) are attractive targets for sensitive molecular imaging, as they are overexpressed in human PC. ${ }^{4}$ Bombesin (BBN)-based peptides show high binding affinity to GRPRs and could be exploited as specific tumor-targeting ligands. ${ }^{5}$ Previous studies have employed several radiolabeled BBN derivatives for GRPR-positive tumor diagnostics and treatment with high efficacy. ${ }^{6-8}$ However, radionuclide imaging suffers from long scan time and ionizing radiation. Recently, some progress has been made in tumor-targeted MR/optical dual-modality 
imaging. ${ }^{9}$ MRI offers several advantages including high anatomical resolution and a lack of harmful radiation. Furthermore, real-time optical imaging is used for intraoperative guidance during surgery. Hence, the design and development of new BBN-based conjugates may provide noninvasive imaging strategies for the detection and localization of GRPR expression in vivo.

Currently, gadolinium oxide $\left(\mathrm{Gd}_{2} \mathrm{O}_{3}\right)$ nanoparticles (NPs) have been investigated for MR molecular imaging. ${ }^{10}$ These NPs can provide high longitudinal relaxivities that are equal to or even larger than clinically approved Gd-DTPA allowing more efficient contrast enhancement. ${ }^{11}$ Moreover, $\mathrm{Gd}_{2} \mathrm{O}_{3} \mathrm{NPs}$ offer a versatile platform for further multifunctionalization through modifications, which makes them good candidates for active tumor targeting and multimodal imaging. ${ }^{12}$

In this study, we report the development of a 5(6)carboxyfluorescein (FI)-conjugated $\mathrm{Gd}_{2} \mathrm{O}_{3}$ nanoprobe for PC cell-specific targeted molecular imaging. $\mathrm{Gd}_{2} \mathrm{O}_{3} \mathrm{NPs}$ were synthesized via a simple polyol-free synthesis at room temperature. The long hydrophilic polyethylene glycol (PEG) segments bearing BBN ligand facilitated specific binding to the overexpressed GRPR, which increased tumor selectivity. ${ }^{13}$ Then, the physicochemical properties and cytotoxicity of $\mathrm{Gd}_{2} \mathrm{O}_{3}$-based nanoprobes were investigated. Cellular uptake efficiency was evaluated by fluorescence microscopy, flow cytometry and in vitro MRI. In vivo MR/optical dual-modality imaging was performed to monitor signal enhancement in the tumors of mice bearing GRPR-positive PC-3 xenografts.

\section{Materials and methods}

\section{Materials and general methods}

Gadolinium(III) acetate, dimethyl sulfoxide (DMSO), tetramethylammonium hydroxide (TMAH), anhydrous EtOH, FI, dichloromethane (DCM), $\alpha$-carboxyl, $\omega$-hydroxy PEG (PEG2000), $N$-hydroxysuccinimide and 1-[3-(dimethylamino) propyl]-3-ethylcarbodiimide hydrochloride $(\mathrm{EDC} \cdot \mathrm{HCl})$ were purchased from Adamas Chemical Reagents Co, Ltd (Shanghai, People's Republic of China). BBN, CGGGQWAVGHLM-NH2(7-14), was synthesized using standard fluorenylmethoxycarbonyl (fmoc) chemistry solid phase peptide synthesis method by Boxin Biotechnology (Xiamen, People's Republic of China). All other chemicals were used without further purification.

\section{Synthesis and sample preparations} Synthesis of the $\mathrm{Gd}_{2} \mathrm{O}_{3} \mathrm{NPs}$

The $\mathrm{Gd}_{2} \mathrm{O}_{3}$ NPs were synthesized according to previously published methods with little modification. ${ }^{14}$ Briefly, Gd
$(\mathrm{OAc})_{3}(670 \mathrm{mg}, 2 \mathrm{mmol})$ was dissolved in DMSO (30 mL). Then, TMAH (200 mg, $5.6 \mathrm{mmol})$ in EtOH (10 mL) was added dropwise. After the total amount of TMAH was added, the mixture was stirred for $2 \mathrm{~h}$ at room temperature. The $\mathrm{Gd}_{2} \mathrm{O}_{3}$ NPs were collected by centrifugation. The particles were washed thoroughly by three cycles of centrifugation/ redispersion in $\mathrm{EtOH}$ and vacuum concentrated to give $\mathrm{Gd}_{2} \mathrm{O}_{3}$ (630 mg, 87\%).

\section{Synthesis of $\mathrm{Gd}_{2} \mathrm{O}_{3}-\mathrm{FI} \mathrm{NPs}$}

$\mathrm{Gd}_{2} \mathrm{O}_{3}(400 \mathrm{mg})$ dispersed in DMSO was reacted with $100 \mathrm{mg}$ FI, under constant stirring for $12 \mathrm{~h}$ at room temperature. $\mathrm{Gd}_{2} \mathrm{O}_{3}$ NPs were capped with a fluorescent glycol-based conjugated carboxylate (H-L) which allowed L coordinated to the surface of $\mathrm{Gd}_{2} \mathrm{O}_{3}$ NPs effectively through the terminal carboxyl group. The product was purified by centrifugation and then washed three times with DMSO, EtOH and DCM sequentially. The pure product was dispersed in deionized (DI) water and freeze-dried to give $\mathrm{Gd}_{2} \mathrm{O}_{3}$-FI NPs (415 mg, 83\%).

\section{Synthesis of $\mathrm{Gd}_{2} \mathrm{O}_{3}$-FI-PEG NPs}

$\mathrm{Gd}_{2} \mathrm{O}_{3}$-FI NPs (200 mg) were mixed with $100 \mathrm{mg}$ PEG-2000 (dissolved in $10 \mathrm{~mL} \mathrm{DMSO}$ ) and reacted at room temperature under constant stirring for $12 \mathrm{~h}$. PEG ligand was coordinated with $\mathrm{Gd}_{2} \mathrm{O}_{3}$ with terminal carboxyl group. The $\mathrm{Gd}_{2} \mathrm{O}_{3}$-FIPEG NPs were collected by centrifugation and then washed three times with DMSO, EtOH and DCM sequentially. Then, $\mathrm{Gd}_{2} \mathrm{O}_{3}$-FI-PEG NPs were obtained to remove impurities. The NPs were added to DI water and freeze-dried to give $\mathrm{Gd}_{2} \mathrm{O}_{3}$ FI-PEG NPs (228 mg, 76\%).

\section{Synthesis of fluorescent GRPR-targeted $\mathrm{Gd}_{2} \mathrm{O}_{3}$ $\left(\mathrm{Gd}_{2} \mathrm{O}_{3}-\mathrm{FI}-\mathrm{PEG}-\mathrm{BBN}\right) \mathrm{NPs}$}

$\mathrm{BBN}$ (20 mg), EDC·HCl (20 mg) and $N$-hydroxysuccinimide $\left(10 \mathrm{mg}\right.$ ) were mixed with $100 \mathrm{mg} \mathrm{Gd}_{2} \mathrm{O}_{3}$-FI-PEG that was dispersed in DMSO. The mixture was stirred for $12 \mathrm{~h}$ at room temperature and then centrifuged. Precipitates were collected by centrifugation and washed with DMSO, EtOH and DCM three times, respectively. The precipitate was dispersed in DI water and freeze-dried to give $\mathrm{Gd}_{2} \mathrm{O}_{3}$-FIPEG-BBN (86 mg, 72\%).

\section{Physicochemical characterization}

The particle size and morphology of the developed NPs were observed using transmission electron microscopy (TEM) (H-7650; HITACHI, Tokyo, Japan) operating at $200 \mathrm{kV}$. The hydrodynamic size distribution of the particles was 
determined using dynamic light scattering (DLS) (Malvern Zeta-sizer 3000HS; Malvern Instruments, Malvern, UK) using a $633 \mathrm{~nm}$ laser. Thermal gravimetric analysis (TGA) was performed on a STA 209 F1 Iris instrument (Netzsch, Selb, Germany). The temperature was increased to $710^{\circ} \mathrm{C}$ at a rate of $10^{\circ} \mathrm{C} \mathrm{min}^{-1}$ (in $100 \mathrm{~mL} \mathrm{~min}{ }^{-1}$ helium flux). Fourier transform infrared (FTIR) spectra were recorded on a Vector 33 FTIR spectrophotometer (Bruker, Mannheim, Germany) using $\mathrm{KBr}$ pellets in the range $4,000-400 \mathrm{~cm}^{-1}$. The $\mathrm{Gd}$ elemental content was determined by inductively coupled plasma atomic emission spectrometry.

\section{Magnetic property measurements}

NPs were prepared in $0,0.25,0.5,1,2$, and $4 \mathrm{mmol} / \mathrm{L} \mathrm{Gd}$ concentrations. Longitudinal relaxivities $\left(r_{1}\right)$ of these suspensions were measured using a 3.0T MR system (Achieva TX; Philips Healthcare, Amsterdam, the Netherlands) equipped with an eight-channel head coil at room temperature. T1 relaxation times for each sample were obtained using T1-weighted spinecho sequences by varying repetition times ( $T R=100,200$, 400,600 , and 1,000 ms) with fixed echo time (TE) $=10 \mathrm{~ms}$, and imaging parameters of slice thickness of $5 \mathrm{~mm}$. The signal intensity of the samples was measured by defining regions of interest in the center of each test tube, and the $\mathrm{T} 1$ values were calculated accordingly using workstation software. The $r_{1}$ values were calculated from the slopes of the linear fitting of $1 / \mathrm{T} 1\left(\mathrm{~s}^{-1}\right)$ versus the $\mathrm{Gd}$ concentration $(\mathrm{mM})$.

\section{In vitro cellular studies}

\section{Cell culture}

The PC-3 cancer cell lines (GRPR positive) were gifted from the Research Center of Clinical Medicine at Nanfang Hospital (Guangzhou, People's Republic of China). PC-3 cells were grown in Dulbecco's Modified Eagle's Medium (DMEM) supplemented with $10 \%$ fetal bovine serum, penicillin $(100 \mathrm{U} / \mathrm{mL})$ and streptomycin $(100 \mathrm{U} / \mathrm{mL})$ in a humidified incubator at $37^{\circ} \mathrm{C}$ with $5 \% \mathrm{CO}_{2}$.

\section{Cytotoxicity assays}

PC-3 cells were seeded in a 96-well plate at a density of 3,000 cells/well and cultured for $24 \mathrm{~h}$. The culture medium was replaced with $200 \mu \mathrm{L}$ DMEM containing $\mathrm{Gd}_{2} \mathrm{O}_{3}$-FI-PEGBBN or control $\mathrm{Gd}_{2} \mathrm{O}_{3}$-FI-PEG at different concentrations $(0.125,0.25,0.5,1,2,4$ and $8 \mathrm{mM} \mathrm{Gd})$ and kept incubated for 24 or $48 \mathrm{~h}$. Subsequently, $20 \mu \mathrm{L}$ of MTT solution $(5 \mathrm{mg} / \mathrm{mL})$ was added and incubated for $4 \mathrm{~h}$ before the addition of $150 \mu \mathrm{L}$ of DMSO into each well to dissolve the formazan crystals. Complete dissolution was achieved by shaking on tabletop oscillator for $10 \mathrm{~min}$. The absorbance of each well was measured at $490 \mathrm{~nm}$ using a BIOTEK ELX80 enzymelinked immunosorbent assay reader (Winooski, VT, USA). The control group contained cells and cell culture medium without NPs.

\section{Analysis of intracellular uptake by fluorescence microscopy}

PC-3 cells were seeded in six-well culture plates at a density of $4 \times 10^{5}$ cells/well and incubated for $24 \mathrm{~h}$. The medium was then removed and replaced with $2 \mathrm{~mL}$ DMEM containing $\mathrm{Gd}_{2} \mathrm{O}_{3}$-FI-PEG-BBN or $\mathrm{Gd}_{2} \mathrm{O}_{3}$-FI-PEG suspensions $(0.8 \mathrm{mM}$ Gd). After incubation at $37^{\circ} \mathrm{C}$ for $4 \mathrm{~h}$, the cells were washed three times with PBS and fixed with $2 \mathrm{~mL} \mathrm{4 \%}$ paraformaldehyde in PBS for $20 \mathrm{~min}$. Cell nuclei were then stained with 4',6-diamidino-2-phenylindole (DAPI). Cellular uptake was observed using a fluorescence microscope (Olympus BX51; Olympus Corporation, Tokyo, Japan).

\section{Cellular uptake measured by flow cytometry}

PC-3 cells were seeded in six-well plates at a density of $4 \times 10^{5}$ cells per well and incubated for $24 \mathrm{~h} . \mathrm{Gd}_{2} \mathrm{O}_{3}$-FI-PEG$\mathrm{BBN}$ or $\mathrm{Gd}_{2} \mathrm{O}_{3}$-FI-PEG NPs $(0.8 \mathrm{mM} \mathrm{Gd})$ were added to the wells and incubated for $4 \mathrm{~h}$. The cells were harvested, and fluorescence was measured using a BD LSRII flow cytometer (BD Biosciences, San Jose, CA, USA).

In vitro cellular MRI

PC-3 cells were grown in DMEM containing both NPs $(0.8 \mathrm{mM} \mathrm{Gd})$ for $4 \mathrm{~h}$, and labeled cells were washed with PBS and resuspended in $100 \mu \mathrm{L}$ of DMEM and $1 \%$ agarose in Eppendorf tubes. The tubes were imaged on a 3.0T MR system with a routine T1-weighted FSE sequence. Parameters were as follows: TR $/ \mathrm{TE}=500 / 10 \mathrm{~ms}$, field of view $=100 \times 100 \times 60 \mathrm{~mm}$, matrix $=256 \times 256$, number of excitation $=2$ and thickness $/$ interval $=4 / 0.5 \mathrm{~mm}$.

\section{Animal experiments and in vivo imaging Tumor model}

Animal experiments were approved by the Institutional Animal Care and Use Committee of Southern Medical University (Guangzhou, People's Republic of China) and performed in accordance with the institutional guidelines. Animals were cared for according to the Chinese National Guidelines for Animal Welfare. For tumor xenografts, a mixture of $6 \times 10^{6} \mathrm{PC}-3$ cells suspended in $0.15 \mathrm{~mL}$ PBS was injected subcutaneously into the left posterior foreleg region of male BALB/c-nude mice (4-5 weeks old). When 
the average tumor diameter reached $1.0 \mathrm{~cm}$ (4-6 weeks after implantation), the mice were randomized into two groups: targeted $\mathrm{Gd}_{2} \mathrm{O}_{3}$-FI-PEG-BBN and non-targeted $\mathrm{Gd}_{2} \mathrm{O}_{3}$-FIPEG, and prepared for further imaging.

\section{In vivo $\mathrm{MRI}$}

Serial MRI was performed on a 3.0T MR system (Achieva TX; Philips Healthcare, the Netherlands) equipped with a mouse-imaging coil before and at different time points after injecting $\mathrm{Gd}_{2} \mathrm{O}_{3}$-FI-PEG-BBN or $\mathrm{Gd}_{2} \mathrm{O}_{3}$-FI-PEG $(3 \mu \mathrm{mol} \mathrm{Gd}$ in $0.2 \mathrm{~mL}, \mathrm{n}=5$ per group). Coronal T1-weighted fast spin echo $(\mathrm{FSE})(\mathrm{TR} / \mathrm{TE}=500 / 10 \mathrm{~ms}$, field of view $=100 \times 100 \times 17 \mathrm{~mm}$, matrix $=320 \times 224$, number of excitation $=3$ and thickness $=2.0 \mathrm{~mm}$ ) images were obtained. Pseudo-colored MRI images were processed with ImageJ software. To estimate the contrast enhancement of NPs in the tumor region, changes in the relative signal intensity were quantified based on the regions of interest.

\section{In vivo near-infrared fluorescent imaging}

To compare the targeting ability of $\mathrm{Gd}_{2} \mathrm{O}_{3}$-FI-PEG-BBN and $\mathrm{Gd}_{2} \mathrm{O}_{3}$-FI-PEG, fluorescent imaging was performed on PC-3 tumor-bearing mice ( $\mathrm{n}=3$ per group) using a Berthold NightOWL LB 983 in vivo imaging system (Bad Wildbad, Germany). The excitation filter was set at $530 \mathrm{~nm}$, and the emission filter was set at $700 \mathrm{~nm}$. Fluorescence images were obtained using a cooled charge-coupled device camera with constant exposure time and taken before and $2 \mathrm{~h}$ after intravenous injection of NPs.

\section{Biodistribution}

To study the tissue distribution of $\mathrm{Gd}_{2} \mathrm{O}_{3}$-FI-PEG-BBN, mice were sacrificed, the major organs (heart, liver, spleen, lung, kidneys and testis) were surgically removed $2 \mathrm{~h}$ postinjection, washed with PBS and imaged by IVIS ${ }^{\circledR}$ Spectrum (PerkinElmer Inc., Waltham, MA, USA) to calculate the average fluorescence intensities within tissues.

\section{Histological analysis}

After in vivo imaging, tumor tissues were collected and embedded in optimal cutting temperature compound. Frozen tumor tissue slices $(5 \mu \mathrm{m})$ were stained with the fluorescent dye DAPI, and images were taken using a fluorescence microscope.

\section{Statistical analysis}

Statistical analysis was performed using a two-tailed unpaired Student's $t$-test with $P<0.05$ used as the cutoff value for significance. All values are presented as mean \pm standard deviation (SD). All analyses were performed using SPSS 13.0 (SPSS Inc., Chicago, IL, USA).

\section{Results and discussion}

The preparation method of $\mathrm{Gd}_{2} \mathrm{O}_{3}$-FI-PEG-BBN was taken from existing literature with slight modifications (Figure 1). ${ }^{14}$ The initial $\mathrm{Gd}_{2} \mathrm{O}_{3}$ NPs were prepared by alkaline hydrolysis of $\mathrm{Gd}(\mathrm{OAC})_{3}$ in aqueous TMAH at room temperature. To improve the biocompatibility and water solubility of $\mathrm{Gd}_{2} \mathrm{O}_{3} \mathrm{NPs}$, the PEGylation strategy was adopted. ${ }^{15}$ The $\mathrm{Gd}_{2} \mathrm{O}_{3}$ NPs then were capped with FI and PEG-2000 in DCM at room temperature to obtain $\mathrm{Gd}_{2} \mathrm{O}_{3}$-FI-PEG, which ensure a biocompatible and stable system and facilitate further modification.

\section{Physicochemical characterization}

TEM was used to investigate the morphology of the developed NPs. Figure $2 \mathrm{~A}$ shows that $\mathrm{Gd}_{2} \mathrm{O}_{3}$-FI-PEG-BBN NPs were almost spherical and had a uniform size with an average diameter of $52.3 \mathrm{~nm}$. The coating layer was visible in TEM images with negative staining. The hydrodynamic diameter of the targeted nanoprobe was $90.6 \mathrm{~nm}$ with a polydispersity index of 0.28 , as measured by DLS (Figure 2B). The difference in size measurements can be attributed to the fact that TEM and DLS showed different morphologies in the solid and swollen states. ${ }^{16}$

Surface coating and functionalization of the samples were investigated by recording the FTIR spectrum. The FTIR spectrum for $\mathrm{Gd}_{2} \mathrm{O}_{3}$ was compared with that of $\mathrm{Gd}_{2} \mathrm{O}_{3}$ FI-PEG-BBN in Figure 2C. After coating $\mathrm{Gd}_{2} \mathrm{O}_{3}$ with PEG and FI, the observed absorption frequencies characteristic of PEG in $\mathrm{Gd}_{2} \mathrm{O}_{3}$-FI-PEG-BBN included the $\mathrm{C}-\mathrm{O}$ stretch at 1,587 and $1,114 \mathrm{~cm}^{-1}$, and the $\mathrm{CH}_{2}$ stretch at 2,920 and $2,856 \mathrm{~cm}^{-1}$. Furthermore, the $\mathrm{C}=\mathrm{O}$ stretch at $1,716 \mathrm{~cm}^{-1}$ was prominent in HO-PEG-COOH and FI but disappeared in $\mathrm{Gd}_{2} \mathrm{O}_{3}$-FI-PEG-BBN, which is consistent with NPs coated by various carboxylic acids. ${ }^{11}$ These data implied that PEG and FI were effectively coordinated to the surface of $\mathrm{Gd}_{2} \mathrm{O}_{3}$ through the terminal carboxyl group. Further modification by $\mathrm{BBN}$ led to a new peak at $1,595 \mathrm{~cm}^{-1}$ corresponding to amide bond formation.

TGA was used to determine the mass drop in weight (\%) of the materials (Figure 2D). The weight loss of both developed NPs was $\sim 20 \%$ due to the thermal decomposition of FI at around $30^{\circ} \mathrm{C}-100^{\circ} \mathrm{C}$ in air. Both nanoprobes showed significant weight loss because low molecular weight PEG degrades at $280^{\circ} \mathrm{C}$. The mass loss of $\mathrm{Gd}_{2} \mathrm{O}_{3}$-FI-PEG$\mathrm{BBN}$ and $\mathrm{Gd}_{2} \mathrm{O}_{3}$-FI-PEG produced at $700^{\circ} \mathrm{C}$ were $51 \%$ and $44 \%$, respectively. Therefore, the extra mass drop of 


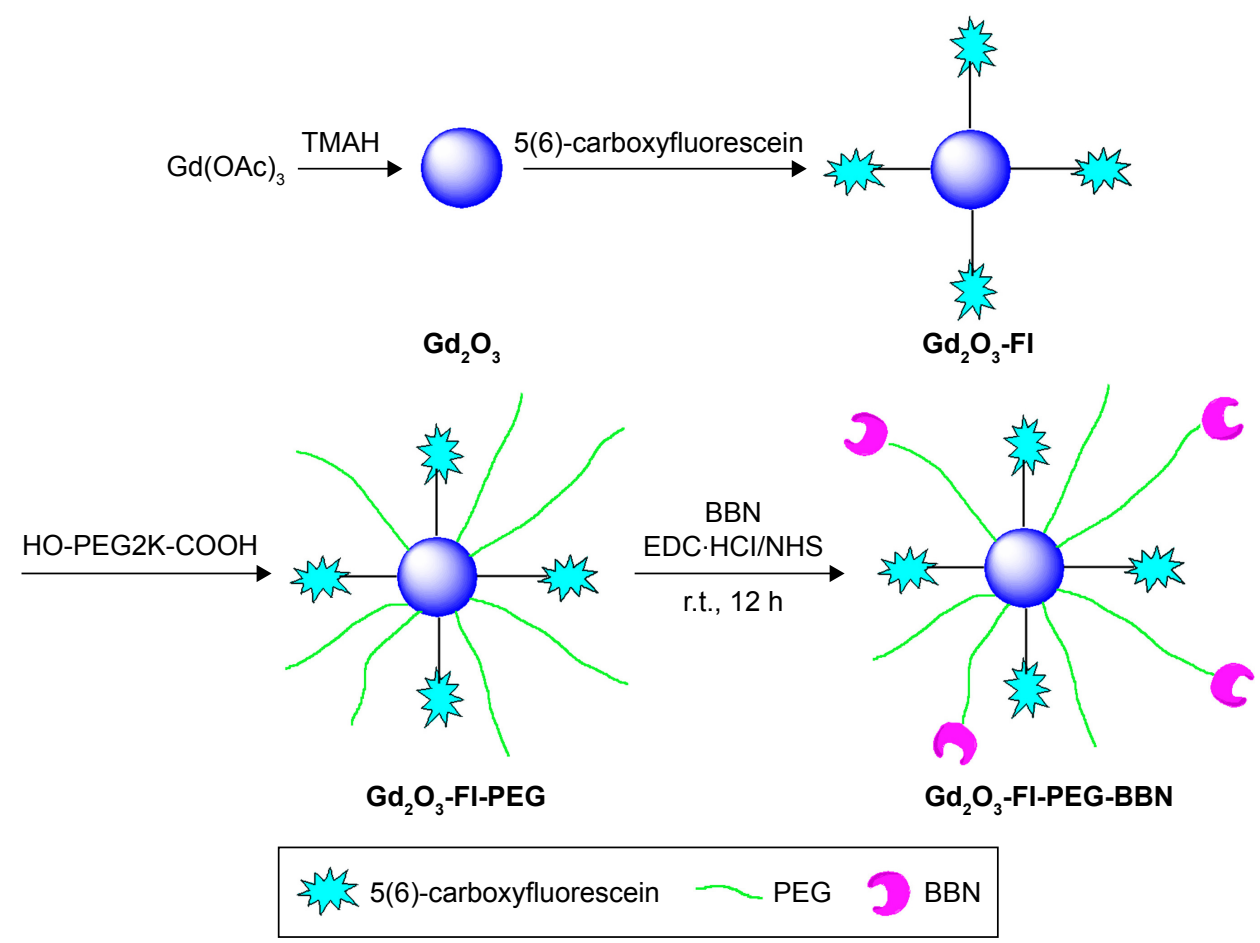

Figure I Schematic illustration of the synthesis of $\mathrm{Gd}_{2} \mathrm{O}_{3}$-FI-PEG-BBN.

Abbreviations: BBN, bombesin; EDC.HCl, I-[3-(dimethylamino)propyl]-3-ethylcarbodiimide hydrochloride; Fl, 5(6)-carboxyfluorescein; $\mathrm{Gd}_{2} \mathrm{O}_{3}$, gadolinium oxide; $\mathrm{NHS}$, $\mathrm{N}$-hydroxysuccinimide; PEG, polyethylene glycol; r.t., room temperature; TMAH, tetramethylammonium hydroxide.
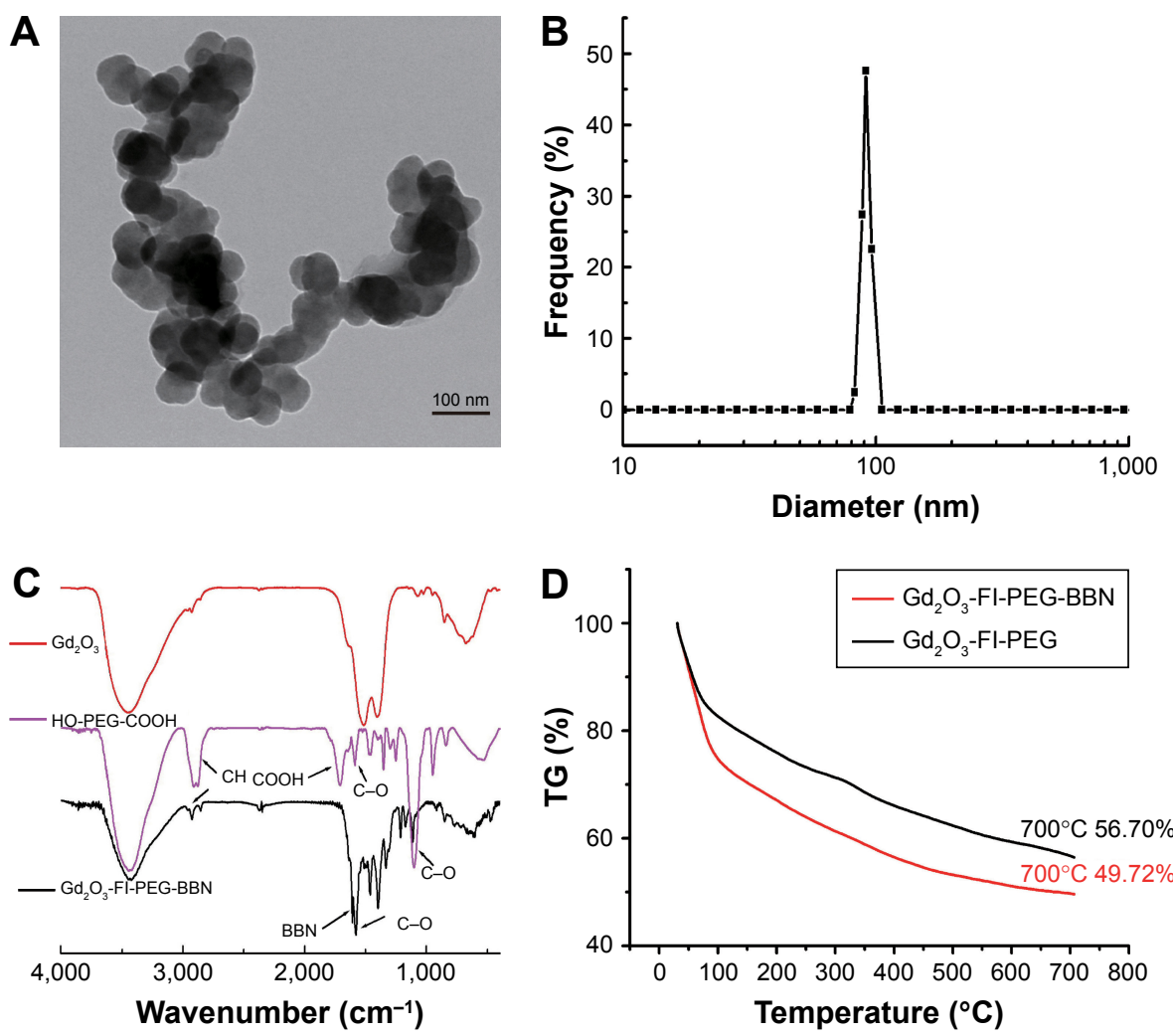
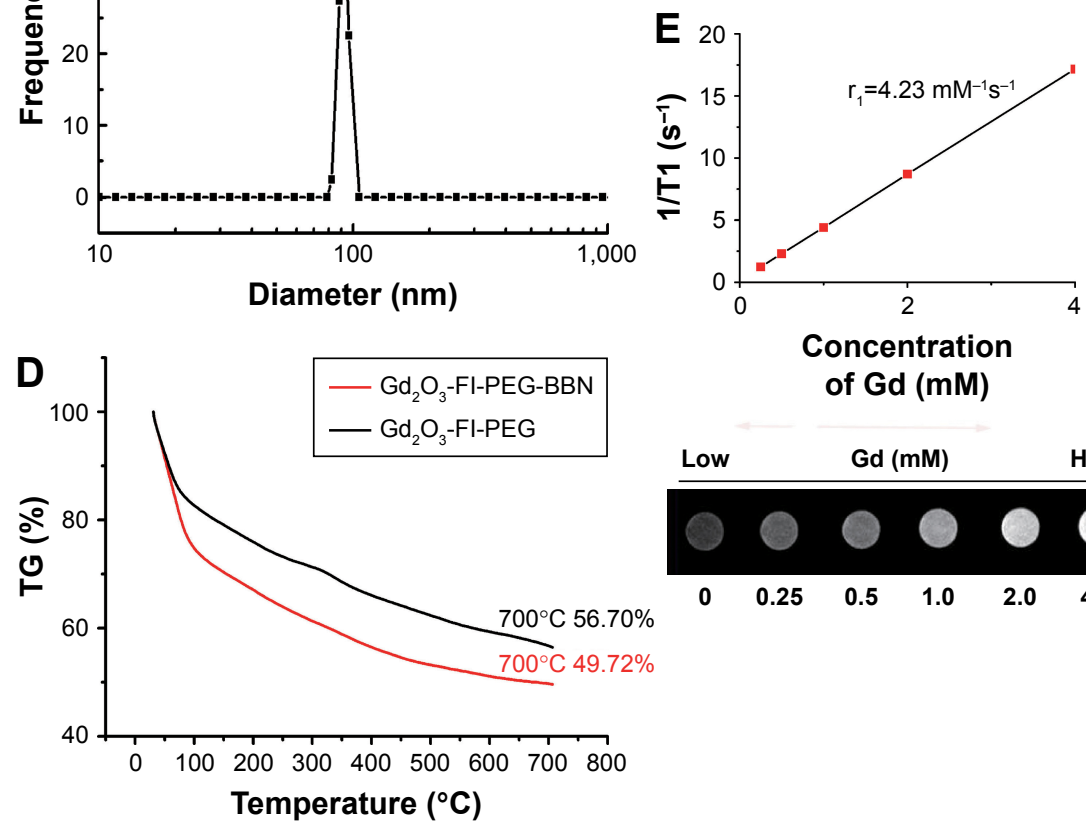

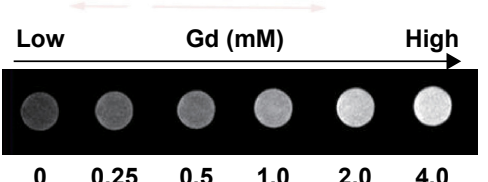

$\begin{array}{llllll}0 & 0.25 & 0.5 & 1.0 & 2.0 & 4.0\end{array}$

Figure 2 Characterization of nanoparticles.

Notes: TEM micrograph (A) and hydrodynamic size distribution (B) of $\mathrm{Gd}_{2} \mathrm{O}_{3}$-FI-PEG-BBN. FTIR spectra $(\mathbf{C})$ of uncoated $\mathrm{Gd}_{2} \mathrm{O}_{3}$ and $\mathrm{Gd}_{2} \mathrm{O}_{3}$-FI-PEG-BBN. TGA curves (D) of $\mathrm{Gd}_{2} \mathrm{O}_{3}-\mathrm{Fl}-\mathrm{PEG}$ and $\mathrm{Gd}_{2} \mathrm{O}_{3}$-FI-PEG-BBN. TI-weighted turbo spin-echo (TSE) MR images and longitudinal relaxation $\mathrm{r}_{1}(\mathbf{E})$ of $\mathrm{Gd}_{2} \mathrm{O}_{3}-\mathrm{FI}-\mathrm{PEG}-\mathrm{BBN}$ solutions with various $\mathrm{Gd}$ concentrations.

Abbreviations: BBN, bombesin; FI, 5(6)-carboxyfluorescein; FTIR, Fourier transform infrared spectroscopy; $\mathrm{Gd}_{2} \mathrm{O}_{3}$, gadolinium oxide; MR, magnetic resonance; PEG, polyethylene glycol; TEM, transmission electron microscopy; TGA, thermal gravimetric analysis. 
$\mathrm{Gd}_{2} \mathrm{O}_{3}$-FI-PEG-BBN (7\%) corresponded to the decomposition of the BBN coating.

\section{Magnetic property measurements}

The ability of contrast agent to alter T1 was assessed via longitudinal relaxivity $\left(\mathrm{r}_{1}\right)$. The T1-weighted MR images (Figure 2E) revealed that MR signals of $\mathrm{Gd}_{2} \mathrm{O}_{3}$-FI-PEG-BBN enhanced as the Gd concentrations increased. As indicated by the slope of the fitting line shown in Figure 2E, the calculated $\mathrm{r}_{1}$ value of $\mathrm{Gd}_{2} \mathrm{O}_{3}$-FI-PEG-BBN was $4.23 \mathrm{mM}^{-1} \mathrm{~s}^{-1}$, which was comparable to that of Magnevist $\left(4.29 \mathrm{mM}^{-1} \mathrm{~s}^{-1}\right)$ reported previously. ${ }^{17}$ The relatively high $\mathrm{r}_{1}$ of $\mathrm{Gd}_{2} \mathrm{O}_{3}$-FIPEG-BBN could be due to the polar $\mathrm{C}=\mathrm{O}$ group increasing the number of exchangeable water molecules in the inner sphere of the $\mathrm{Gd}^{3+}$ ions, which is known to be directly related to contrast enhancing capacity. ${ }^{18}$ This suggests that $\mathrm{Gd}_{2} \mathrm{O}_{3}$ FI-PEG-BBN can serve as a highly efficient T1-weighted MRI contrast agent.

\section{Cytotoxicity assay}

The in vitro cytotoxicity of $\mathrm{Gd}_{2} \mathrm{O}_{3}$-FI-PEG and $\mathrm{Gd}_{2} \mathrm{O}_{3}$-FIPEG-BBN was evaluated by MTT viability assays. Figure 3 shows the viability of PC-3 cells incubated with both NPs at various Gd concentrations $(0-8 \mathrm{mM})$. Even at $8 \mathrm{mM} \mathrm{Gd}$, the cell viability remained $112.9 \% \pm 3.6 \%$ after $24 \mathrm{~h}$ and $110.2 \% \pm 6.8 \%$ after $48 \mathrm{~h}$ incubation with $\mathrm{Gd}_{2} \mathrm{O}_{3}$-FI-PEGBBN. Similarly, no significant cell viability reduction was observed for $\mathrm{Gd}_{2} \mathrm{O}_{3}$-FI-PEG. In accordance to other published data, ${ }^{19,20} \mathrm{Gd}_{2} \mathrm{O}_{3}$-based NPs did not present any cytotoxic activity. These results indicated that $\mathrm{Gd}_{2} \mathrm{O}_{3}$-FI-PEG and $\mathrm{Gd}_{2} \mathrm{O}_{3}$-FI-PEG-BBN are relatively biocompatible and have low toxicity at this Gd concentration range.

\section{Specificity of targeting PC-3 cells in vitro}

To investigate the targeting efficacy and intracellular distribution of the developed probes, we incubated the $\mathrm{Gd}_{2} \mathrm{O}_{3}$ nanoprobe with GRPR-positive PC-3 cells. The green fluorescence of FI was used for the observation of GRPRmediated intracellular delivery. As shown in Figure 4A, green fluorescence was clearly observed in PC-3 cells treated with $\mathrm{Gd}_{2} \mathrm{O}_{3}$-FI-PEG-BBN. However, only weak green fluorescence was detected in cells incubated with $\mathrm{Gd}_{2} \mathrm{O}_{3}$-FI-PEG. This was attributed to the fact that BBN can remarkably enhance NPs uptake through GRPR-mediated endocytosis. ${ }^{21}$ Moreover, fluorescence microscopy images showed that $\mathrm{Gd}_{2} \mathrm{O}_{3}$-FI-PEG-BBN fluorescence was predominantly accumulated in the cytoplasm around the nucleus.

\section{Cellular uptake by flow cytometry}

The uptake of $\mathrm{Gd}_{2} \mathrm{O}_{3}$-FI-PEG-BBN in PC-3 cells was also studied by flow cytometry. As shown in Figure 4B, cells incubated with $\mathrm{Gd}_{2} \mathrm{O}_{3}$-FI-PEG-BBN NPs showed much higher fluorescence intensity than those incubated with $\mathrm{Gd}_{2} \mathrm{O}_{3}$-FI-PEG and the blank cells. The area under each curve was proportional to the total number of fluorescent cells and was $\sim 7.4$ fold higher in $\mathrm{Gd}_{2} \mathrm{O}_{3}$-FI-PEG-BBN than in non-targeted
A

$24 \mathrm{~h}$

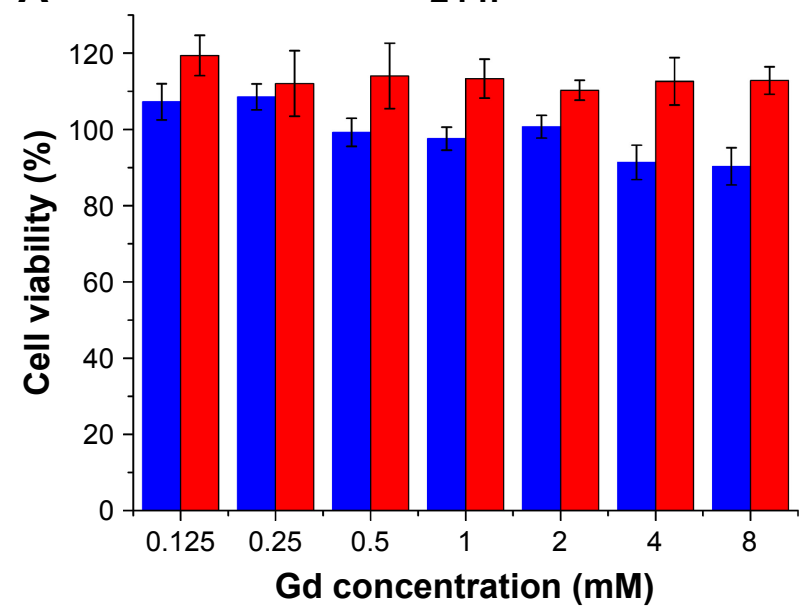

B

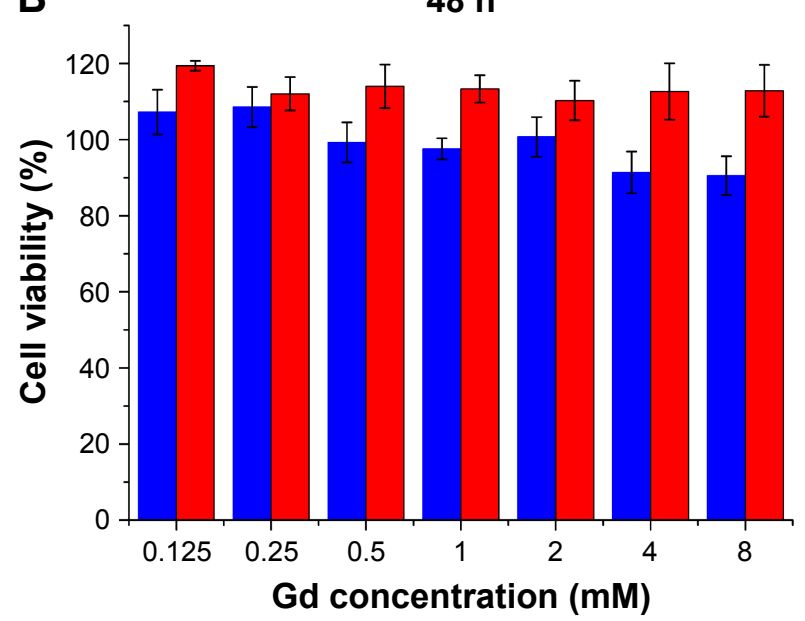

$\mathrm{Gd}_{2} \mathrm{O}_{3}$-FI-PEG $\square \mathrm{Gd}_{2} \mathrm{O}_{3}$-FI-PEG-BBN

Figure 3 Cell viability assays of PC-3 cells treated with various concentrations of $\mathrm{Gd}_{2} \mathrm{O}_{3}$-FI-PEG-BBN or $\mathrm{Gd}_{2} \mathrm{O}_{3}-\mathrm{Fl}-\mathrm{PEG}$ for 24 (A) or 48 h (B). Abbreviations: BBN, bombesin; $\mathrm{Fl}, 5(6)$-carboxyfluorescein; $\mathrm{Gd}_{2} \mathrm{O}_{3}$, gadolinium oxide; PEG, polyethylene glycol. 
A
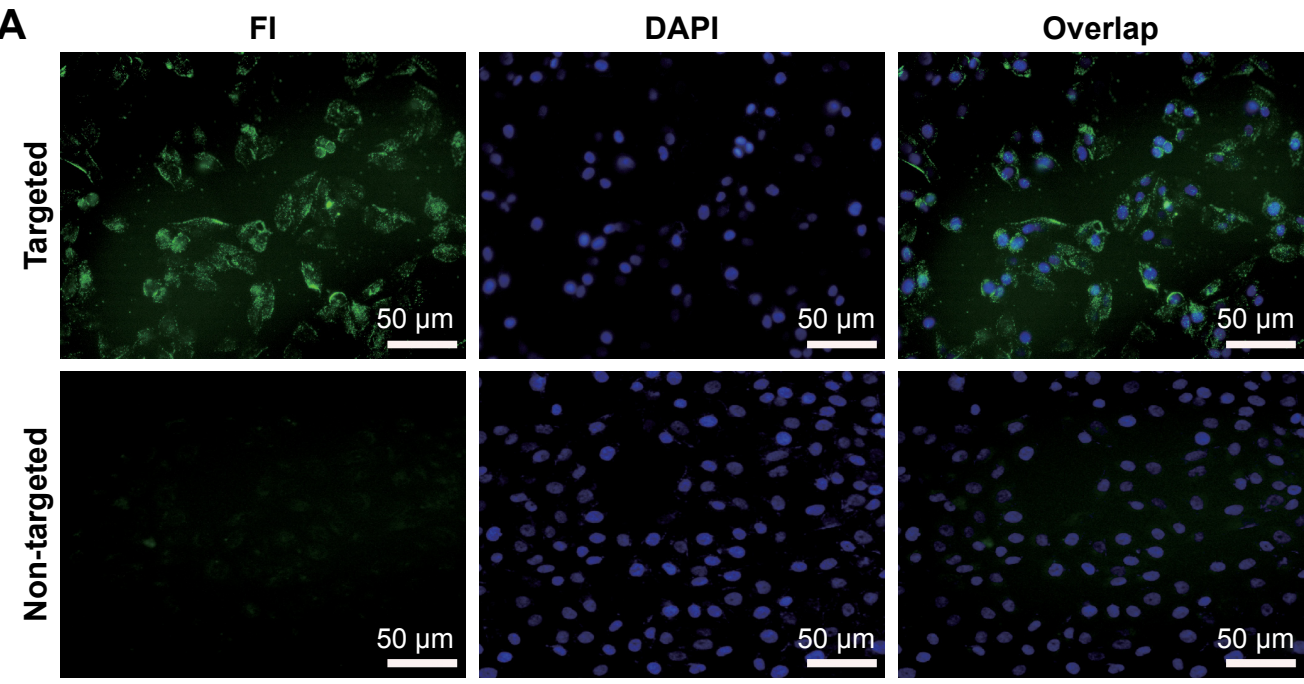

B

Blank control

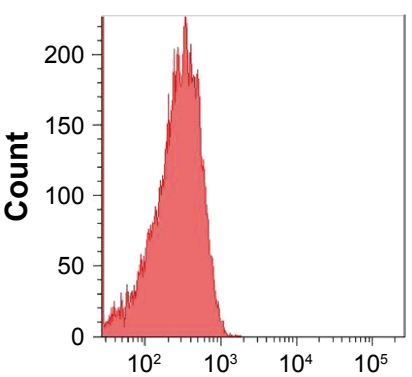

Fluorescent intensity

C
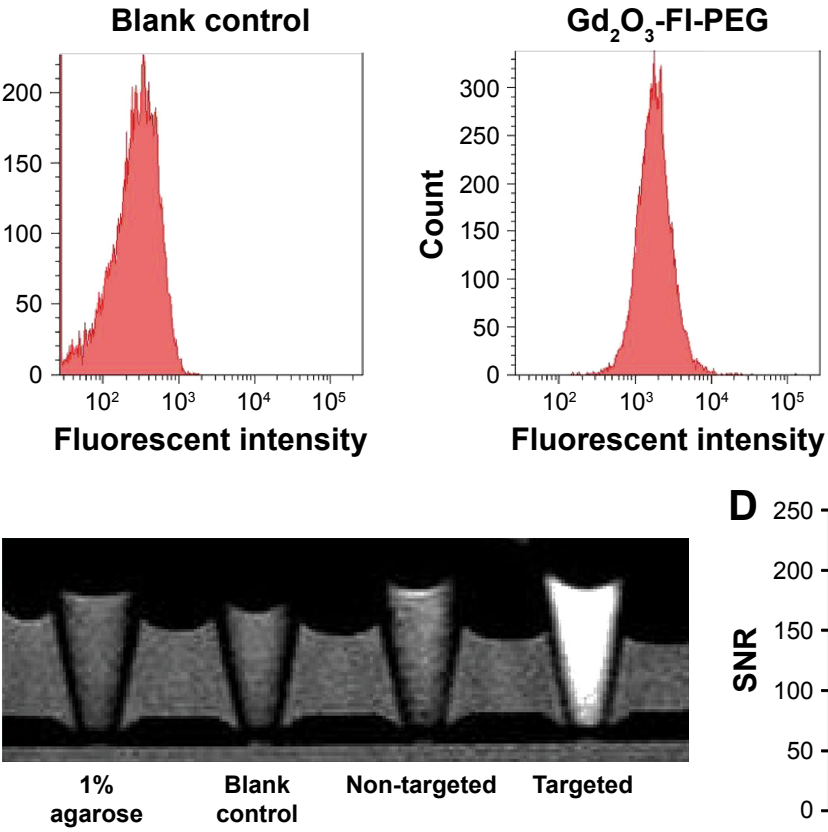

$\mathrm{Gd}_{2} \mathrm{O}_{3}$-FI-PEG-BBN

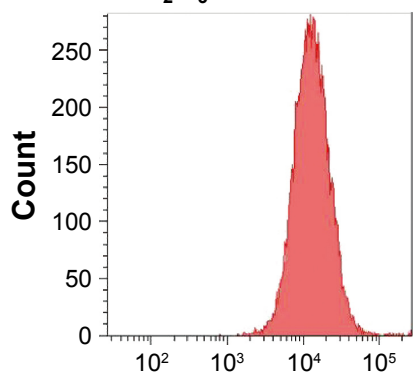

Fluorescent intensity

Fluorescent intensity

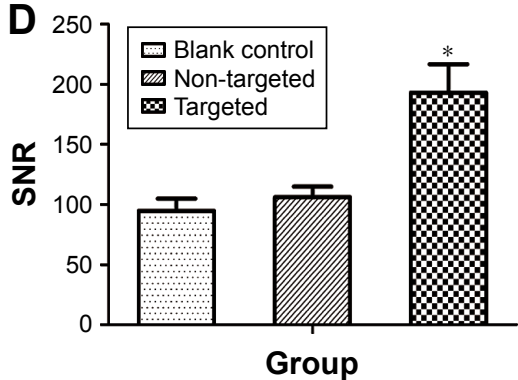

Figure 4 Fluorescence microscopy images $(\mathbf{A})$, flow cytometry $(\mathbf{B}), \mathrm{TI}$-weighed TSE MR images $(\mathbf{C})$ and $M R I$ signal intensity plots $(\mathbf{D})$ of the cellular uptake of Gd ${ }_{2} \mathrm{O}_{3}$-based nanoprobes by PC-3 cells.

Notes: (A) FI fluorescence (green), excited by green light, is shown in the left panel. DAPI counterstained nuclei (blue), excited by blue light, are shown in the middle panel. Color overlays of green and blue fluorescence are shown in the right panel. ${ }^{*} P<0.05$.

Abbreviations: BBN, bombesin; FI, 5(6)-carboxyfluorescein; $\mathrm{Gd}_{2} \mathrm{O}_{3}$, gadolinium oxide; MRI, magnetic resonance imaging; PEG, polyethylene glycol; SNR, signal-to-noise ratio; TSE, turbo spin-echo.

controls. This indicated that the addition of BBN peptide to the NPs enhanced NP uptakes.

\section{In vitro cellular MRI}

The enhanced cellular uptake of the targeted nanoprobe was further confirmed by T1-weighted MRI in vitro. Figure 4C and $\mathrm{D}$ show that the T1 signal intensity of PC-3 cells incubated with $\mathrm{Gd}_{2} \mathrm{O}_{3}$-FI-PEG-BBN increased according to $\mathrm{Gd}$ concentrations. These MRI results further demonstrated that surface functionalization by BBN enhanced the cellular uptake efficacy of NPs by specifically binding to overexpressed GRPR in cancer cells. ${ }^{22}$

\section{In vivo MRI}

To investigate the tumor targeting ability of the developed nanoprobe in vivo, serial T1-weighted images of PC-3 tumorbearing mice were acquired before and at different time points after intravenous injection of $\mathrm{Gd}_{2} \mathrm{O}_{3}$-FI-PEG-BBN 
or $\mathrm{Gd}_{2} \mathrm{O}_{3}$-FI-PEG. As shown in Figure 5A, the targeted $\mathrm{Gd}_{2} \mathrm{O}_{3}$-FI-PEG-BBN reached a peak MRI signal intensity $2 \mathrm{~h}$ postinjection and showed more obvious and prolonged signal enhancement in the tumor than the non-targeted probe after injection. MRI signal intensities of PC-3 tumors before and $2 \mathrm{~h}$ after injection were measured and plotted in Figure 5B for quantitative analysis. The targeted nanoprobe resulted in a higher enhancement ratio than the non-targeted probe (27.9\% $\pm 5.9 \%$ versus $4.0 \% \pm 2.2 \%$, respectively, $P<0.05)$. According to our in vivo MRI results, the targeted $\mathrm{Gd}_{2} \mathrm{O}_{3}$ FI-PEG-BBN nanoprobe accumulated in cancerous tissues through the enhanced permeation and retention effect and
A
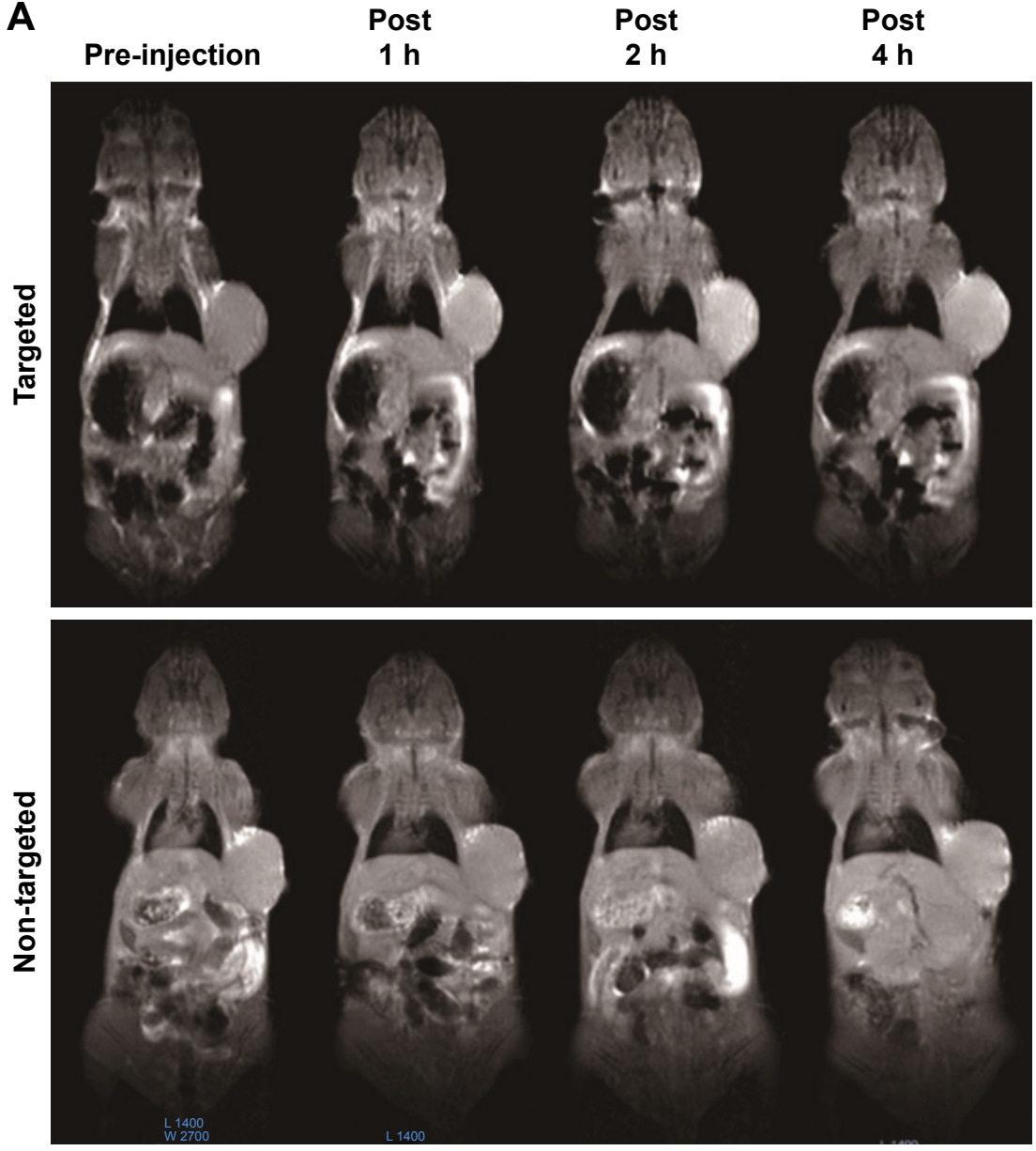

Pseudocolor post $2 \mathrm{~h}$
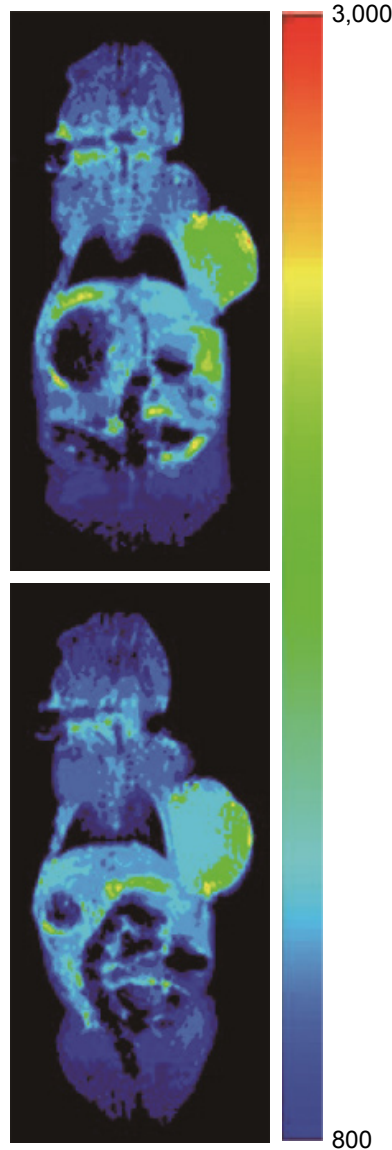

B

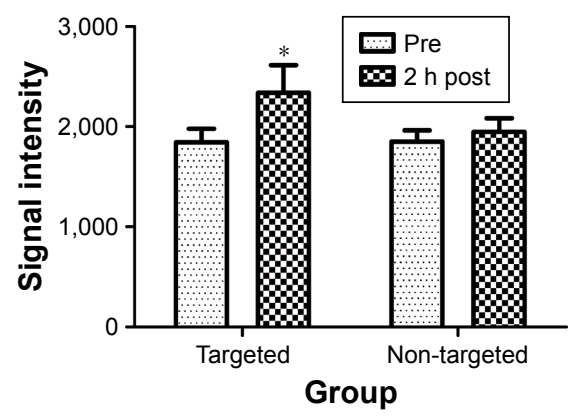

C

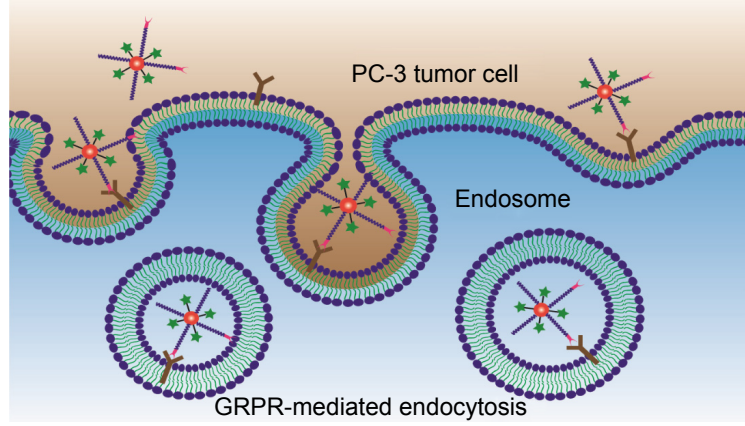

Figure 5 In vivo MR imaging.

Notes: Representative in vivo serial TI-weighted MR images $(\mathbf{A})$ before and at I, 2, and 4 h postinjection of targeted $\mathrm{Gd}_{2} \mathrm{O}_{3}-\mathrm{Fl}-\mathrm{PEG}-\mathrm{BBN}_{\mathrm{B}}$ or non-targeted $\mathrm{Gd}_{2} \mathrm{O}_{3}-\mathrm{FI}-\mathrm{PEG}$ and pseudocolor maps of MR images $2 \mathrm{~h}$ after administering each agent. Quantitative analysis of signal intensity in the tumor region (B) of PC-3 tumor-bearing mice before and $2 \mathrm{~h}$ after intravenous injection. Schematic representation (C) of GRPR-mediated intracellular delivery. $* P<0.05$.

Abbreviations: BBN, bombesin; FI, 5(6)-carboxyfluorescein; $\mathrm{Gd}_{2} \mathrm{O}_{3}$, gadolinium oxide; GRPR, gastrin-releasing peptide receptor; MR, magnetic resonance; PEG, polyethylene glycol. 
exhibited active targeting ability and selectively accumulated in the tumor sites (Figure 5C), which achieved the maximal contrast enhancement. ${ }^{23}$

\section{In vivo fluorescent imaging and biodistribution}

The fluorescence intensity in tumors from the $\mathrm{Gd}_{2} \mathrm{O}_{3}$-FIPEG-BBN nanoprobe was substantially greater than that in the non-targeted group, which indicated highly specific targeting of the $\mathrm{Gd}_{2} \mathrm{O}_{3}$-FI-PEG-BBN nanoprobe to PC-3 tumors (Figure 6A). As illustrated in Figure 6B, the NPs primarily accumulated in tumors. Significant fluorescence signal was also observed in the liver, spleen, lung, kidney and testis (Figure 6C), similar to the in vivo behaviors of many other nanomaterials applied in biomedicine. ${ }^{24,25}$ Conversely, the nonspecific fluorescence distribution might be due to fluorescein dissociation from the nanoprobe. Therefore, the long-term fate of $\mathrm{Gd}_{2} \mathrm{O}_{3}$-FI-PEG-BBN requires further investigation.

\section{Histological studies}

Ex vivo fluorescence microscopy was used to further verify the accumulation of the developed nanoprobe in tumors. As shown in Figure 7, abundant green fluorescence was seen in tumor tissues after injecting $\mathrm{Gd}_{2} \mathrm{O}_{3}$-FI-PEG-BBN, but only a little green fluorescence was observed in the non-targeted group. This result demonstrated increased accumulation of targeted $\mathrm{Gd}_{2} \mathrm{O}_{3}$-FI-PEG-BBN in tumors that exhibited clear MRI contrast. ${ }^{26}$ These results further confirmed the GRPR tumor-specific uptake of the targeted nanoprobe.

\section{Conclusion}

In summary, we have synthesized a BBN-modified $\mathrm{Gd}_{2} \mathrm{O}_{3}$ based nanoprobe with relatively good water dispersibility and favorable biocompatibility. PEG coating allowed modification with BBN ligand, which ensured the selective PC-3 cellular uptake, thus paving a way toward targeted delivery to PC tissues and the visualization of its accumulation by in vitro and in vivo MRI/fluorescent imaging. These multifunctional
A
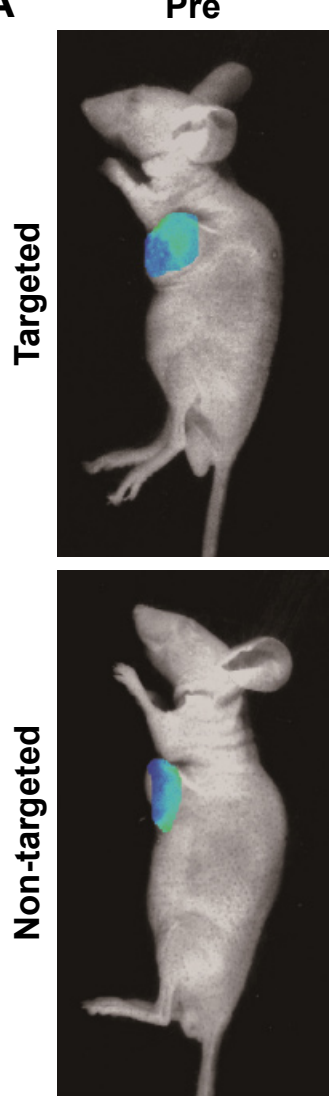

Post $2 \mathrm{~h}$
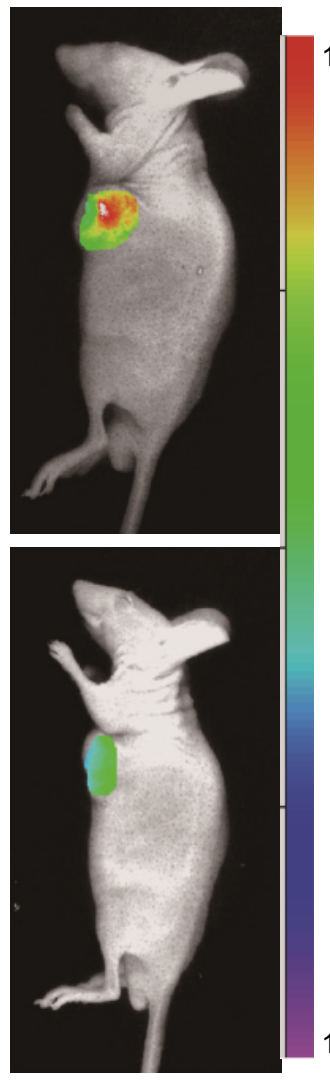

B

1,400

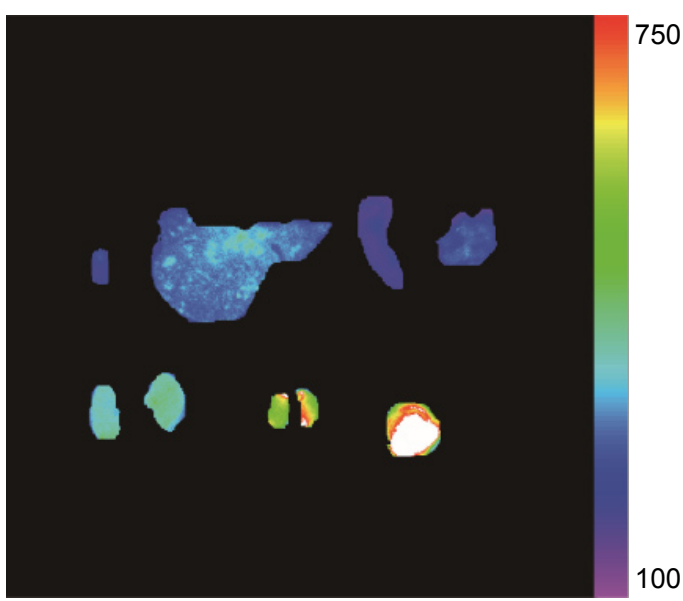

C

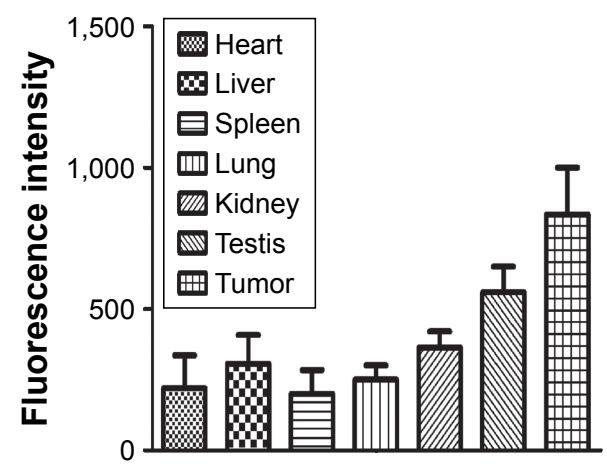

Figure 6 In vivo fluorescent imaging and biodistribution.

Notes: In vivo optical images (A) of nude mice bearing subcutaneous PC-3 tumor xenografts after intravenous injection of $\mathrm{Gd}_{2} \mathrm{O}_{3}-\mathrm{FI}-\mathrm{PEG}-\mathrm{BBN}_{\text {or }} \mathrm{Gd}{ }_{2} \mathrm{O}_{3}-\mathrm{Fl}-\mathrm{PEG}$. Ex vivo fluorescence images (B) of dissected organs from mice bearing PC-3 tumors sacrificed after injecting $\mathrm{Gd}_{2} \mathrm{O}_{3}-\mathrm{FI}-\mathrm{PEG}-\mathrm{BBN}$. Quantitative fluorescent intensities of isolated tumors and main organs (C).

Abbreviations: $\mathrm{BBN}$, bombesin; $\mathrm{FI}, 5(6)$-carboxyfluorescein; $\mathrm{Gd}_{2} \mathrm{O}_{3}$, gadolinium oxide; PEG, polyethylene glycol. 

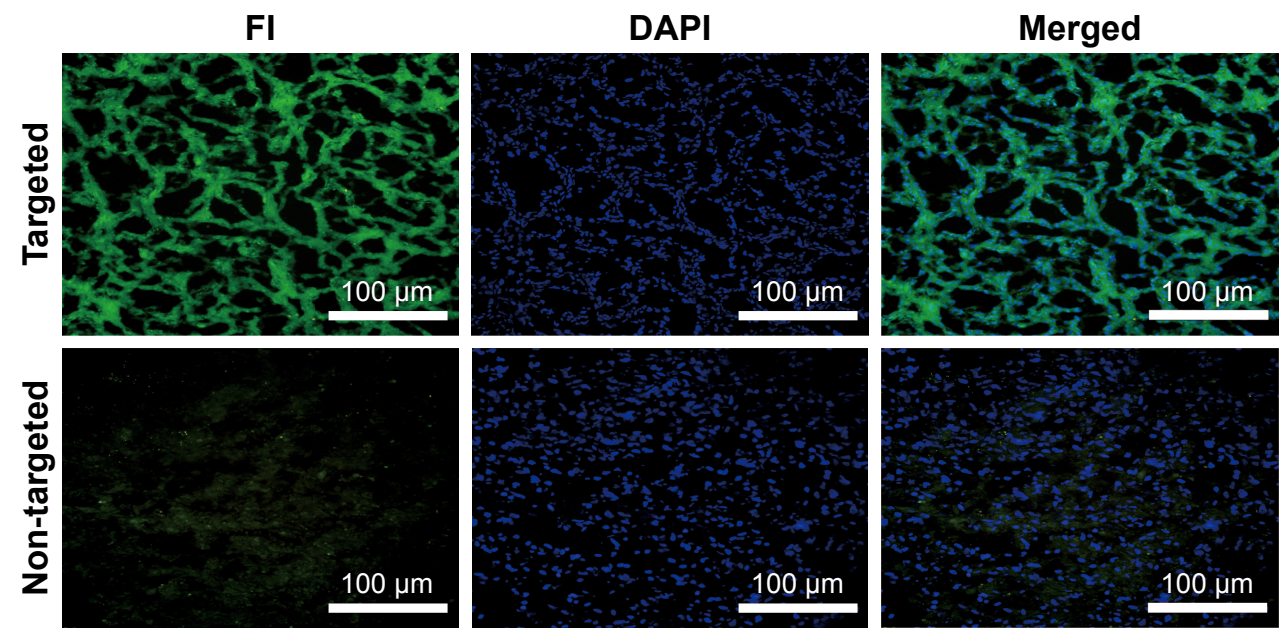

Figure 7 Fluorescence microscopy images of tumor tissues after intravenously injecting targeted $\mathrm{Gd}_{2} \mathrm{O}_{3}$-FI-PEG-BBN or non-targeted $\mathrm{Gd}{ }_{2} \mathrm{O}_{3}-\mathrm{Fl}-\mathrm{PEG}$. Abbreviations: $\mathrm{BBN}$, bombesin; $\mathrm{FI}, 5(6)$-carboxyfluorescein; $\mathrm{Gd}_{2} \mathrm{O}_{3}$, gadolinium oxide; PEG, polyethylene glycol.

$\mathrm{Gd}_{2} \mathrm{O}_{3}$-based NPs may be a potential nanoplatform for combined molecular cancer diagnosis and targeted antitumor drug delivery in future clinical applications.

\section{Acknowledgments}

We thank Yingjie Mei (Philips Healthcare, People's Republic of China) for technical assistance in MRI data acquisition and postprocessing. This work was supported by the National Research Foundation of China (numbers 81271642 and 81671749) and the Science and Technology Planning Project of Guangdong Province (2015B020233019).

\section{Disclosure}

The authors report no conflicts of interest in this work.

\section{References}

1. Siegel RL, Miller KD, Jemal A. Cancer statistics, 2017. CA Cancer J Clin. 2017;67(1):7-30.

2. Wolf AM, Wender RC, Etzioni RB, et al; American Cancer Society Prostate Cancer Advisory Committee. American Cancer Society guideline for the early detection of prostate cancer: update 2010. CA Cancer J Clin. 2010;60(2):70-98.

3. Woodrum DA, Kawashima A, Gorny KR, Mynderse LA. Prostate cancer: state of the art imaging and focal treatment. Clin Radiol. 2017; 72(8):665-679.

4. Beer M, Montani M, Gerhardt J, et al. Profiling gastrin-releasing peptide receptor in prostate tissues: clinical implications and molecular correlates. Prostate. 2012;72(3):318-325.

5. Wieser G, Mansi R, Grosu AL, et al. Positron emission tomography (PET) imaging of prostate cancer with a gastrin releasing peptide receptor antagonist - from mice to men. Theranostics. 2014;4(4):412-419.

6. Zhang J, Niu G, Lang L, et al. Clinical Translation of a dual integrin alphavbeta3- and gastrin-releasing peptide receptor-targeting PET radiotracer, 68Ga-BBN-RGD. J Nucl Med. 2017;58(2):228-234.

7. Lim JC, Cho EH, Kim JJ, et al. Preclinical pharmacokinetic, biodistribution, imaging and therapeutic efficacy of (177)Lu-labeled glycated bombesin analogue for gastrin-releasing peptide receptor-positive prostate tumor targeting. Nucl Med Biol. 2015;42(3):234-241.
8. Richter S, Wuest M, Krieger SS, et al. Synthesis and radiopharmacological evaluation of a high-affinity and metabolically stabilized $18 \mathrm{~F}-$ labeled bombesin analogue for molecular imaging of gastrin-releasing peptide receptor-expressing prostate cancer. Nucl Med Biol. 2013; 40(8):1025-1034.

9. Liang J, Zhang X, Miao Y, Li J, Gan Y. Lipid-coated iron oxide nanoparticles for dual-modal imaging of hepatocellular carcinoma. Int $J$ Nanomedicine. 2017;12:2033-2044.

10. Ni K, Zhao Z, Zhang Z, et al. Geometrically confined ultrasmall gadolinium oxide nanoparticles boost the T(1) contrast ability. Nanoscale. 2016;8(6):3768-3774.

11. Liu J, Huang L, Tian X, et al. Magnetic and fluorescent Gd2O3: Yb3+/ $\mathrm{Ln} 3+$ nanoparticles for simultaneous upconversion luminescence/MR dual modal imaging and NIR-induced photodynamic therapy. Int $J$ Nanomedicine. 2017;12:1-14.

12. Han L, Xia JM, Hai X, Shu Y, Chen XW, Wang JH. Protein-stabilized gadolinium oxide-gold nanoclusters hybrid for multimodal imaging and drug delivery. ACS Appl Mater Interfaces. 2017;9(8):6941-6949.

13. Steinmetz NF, Ablack AL, Hickey JL, et al. Intravital imaging of human prostate cancer using viral nanoparticles targeted to gastrin-releasing peptide receptors. Small. 2011;7(12):1664-1672.

14. Hu Z, Ahren M, Selegard L, et al. Highly water-dispersible surfacemodified $\mathrm{Gd}(2) \mathrm{O}(3)$;nanoparticles for potential dual-modal bioimaging. Chemistry. 2013;19(38):12658-12667.

15. Nan X, Zhang X, Liu Y, Zhou M, Chen X, Zhang X. Dual-targeted multifunctional nanoparticles for magnetic resonance imaging guided cancer diagnosis and therapy. ACS Appl Mater Interfaces. 2017;9(11): 9986-9995.

16. Xia Y, Wang Y, Wang Y, et al. A tumor pH-responsive complex: carboxyl-modified hyperbranched polyether and cis-dichlorodiammineplatinum(II). Colloids Surf B Biointerfaces. 2011;88(2): 674-681.

17. Gong H, Dong ZL, Liu YM, et al. Engineering of multifunctional nano-micelles for combined photothermal and photodynamic therapy under the guidance of multimodal imaging. Adv Funct Mater. 2014; 24(41):6492-6502.

18. Anishur RA, Majewski P, Vasilev K. Gd2O3 nanoparticles: sizedependent nuclear magnetic resonance. Contrast Media Mol Imaging. 2013;8(1):92-95.

19. Wang F, Peng E, Liu F, Li P, Li SF, Xue JM. Fluorescence-tagged amphiphilic brush copolymer encapsulated $\mathrm{Gd} 2 \mathrm{O} 3$ core-shell nanostructures for enhanced T1 contrast effect and fluorescent imaging. Nanotechnology. 2016;27(42):425101. 
20. Kumar S, Meena VK, Hazari PP, Sharma RK. FITC-Dextran entrapped and silica coated gadolinium oxide nanoparticles for synchronous optical and magnetic resonance imaging applications. Int J Pharm. 2016; 506(1-2):242-252.

21. Pan D, Yan Y, Yang R, et al. PET imaging of prostate tumors with 18F-Al-NOTA-MATBBN. Contrast Media Mol Imaging. 2014;9(5): 342-348.

22. Chen $\mathrm{H}$, Wan $\mathrm{S}$, Zhu F, et al. A fast tumor-targeting near-infrared fluorescent probe based on bombesin analog for in vivo tumor imaging. Contrast Media Mol Imaging. 2014;9(2):122-134.

23. Jia Z, Song L, Zang F, et al. Active-target T1-weighted MR imaging of tiny hepatic tumor via RGD modified ultra-small $\mathrm{Fe}_{3} \mathrm{O}_{4}$ nanoprobes. Theranostics. 2016;6(11):1780-1791.
24. Lin YH, Dayananda $\mathrm{K}$, Chen $\mathrm{CY}$, et al. In vivo MR/optical imaging for gastrin releasing peptide receptor of prostate cancer tumor using GdTTDA-NP-BN-Cy5.5. Bioorg Med Chem. 2011;19(3):1085-1096.

25. Naccache R, Chevallier $P$, Lagueux J, et al. High relaxivities and strong vascular signal enhancement for NaGdF4 nanoparticles designed for dual MR/optical imaging. Adv Healthc Mater. 2013;2(11):1478-1488.

26. Zhou Z, Han Z, Lu ZR. A targeted nanoglobular contrast agent from host-guest self-assembly for MR cancer molecular imaging. Biomaterials. 2016;85:168-179.
International Journal of Nanomedicine

\section{Publish your work in this journal}

The International Journal of Nanomedicine is an international, peerreviewed journal focusing on the application of nanotechnology in diagnostics, therapeutics, and drug delivery systems throughout the biomedical field. This journal is indexed on PubMed Central, MedLine, CAS, SciSearch $®$, Current Contents $® /$ Clinical Medicine,

\section{Dovepress}

Journal Citation Reports/Science Edition, EMBase, Scopus and the Elsevier Bibliographic databases. The manuscript management system is completely online and includes a very quick and fair peer-review system, which is all easy to use. Visit http://www.dovepress.com/ testimonials.php to read real quotes from published authors.

Submit your manuscript here: http://www.dovepress.com/international-journal-of-nanomedicine-journal 